\title{
TINDAKAN PERCABULAN DITINJAU DARI KACAMATA FILSAFAT MANUSIA
}

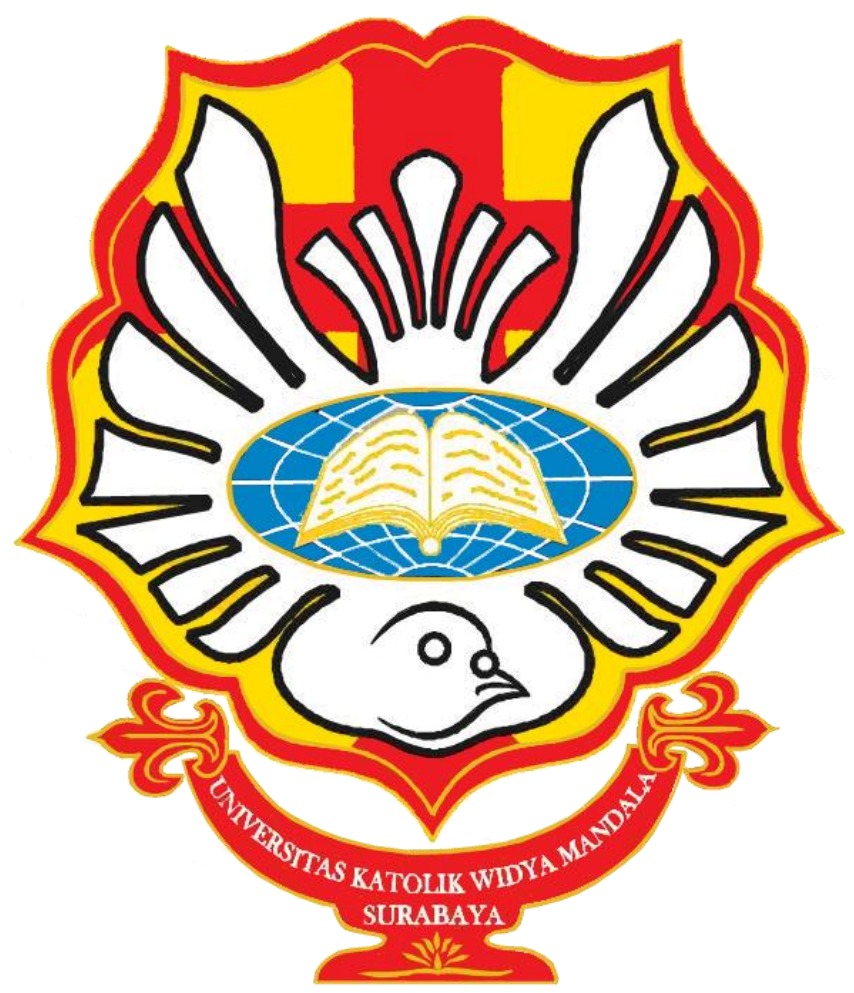

Ditulis oleh:

Yudho Prasetio (41417012)

FAKULTAS TEKNIK

PROGRAM STUDI TEKNIK INDUSTRI UNIVERSITAS KATOLIK WIDYA MANDALA SURABAYA KAMPUS MADIUN 


\begin{abstract}
Abstrak
Manusia diberkahi oleh Tuhan dengan akal budi dan bentuk fisik yang sempurna. Manusia juga diciptakan memiliki kebebasan dalam berpikir maupun bertindak. Namun kebebasan ini seringkali disalahgunakan oleh setiap orang. Bukan mengarah pada kebaikan namun justru pada keburukan. Keburukan untuk diri sendiri maupun orang lain. Salah satunya adalah tindakan menyimpang yaitu percabulan. Tindakan ini merupakan tindakan yang sangat tidak dibenarkan baik dari sisi hukum maupun agama. Banyak korban yang menjadi sasaran si pelaku baik itu orang dewasa bahkan anak-anak. Umumnya kasus ini terjadi dan dialami oleh perempuan yang notabenya memiliki kekuatan fisik yang lemah dari pada laki-laki. Percabulan membuat manusia dapat dikatakan seperti hewan dimana mereka hanya bergerak berdasarkan instingnya saja dan tidak menggunakan rasio akal budinya sebagai manusia. Manusia memiliki kebebasan namun digunakan hanya untuk kepuasan diri dan merugikan orang banyak. Perilaku semacam ini bukan hanya menjauhkan diri kepada kebaikan terhadap manusia lain, juga kepada Tuhan yang sudah menciptakan seluruh alam semesta beserta isinya. Dorongan untuk berbuat baik terhalang oleh hawa nafsu sementara tanpa adanya keinginan untuk menjadi manusia yang memanusiakan orang lain. Tindakan manusiawi membuat manusia berbeda dengan hewan. Manusia bertindak melalui pikirannya untuk berbuat baik kepada sesama. Berbeda dengan hewan yang bertindak berdasarkan instingnya saja. Maka diperlukan pemahaman mengenai apa itu menjadi manusia yang bertindak menggunakan rasio inteleknya untuk memanusiakan orang lain yang menuju pada kebaikan untuk diri sendiri dan orang lain
\end{abstract}

Kata Kunci: Intelek, Kebebasan, Tindakan Manusia, Percabulan, Memanusiakan Manusia, Manusiawi. 
Dewasa ini banyak sekali perkembangan yang terjadi di dunia, baik itu perkembangan tentang teknologi, informasi, kebutuhan hidup, dll. Tidak seperti dulu yang perkembangannya membutuhkan waktu yang cukup lama karena keterbatasan pengetahuan dan teknologi, sekarang manusia sedang berada dalam fase dimana perkembangan terjadi begitu pesat karena terdapat ilmu pengetahuan dan teknologi canggih didalamnya. Manusia semakin dituntut untuk berpikir secara lebih cerdas dan bijak. Lebih cerdas ini yang dimaksud adalah berpikir secara lebih terperinci dan cepat dalam mengambil suatu tindakan, jika kita salah langkah dalam mengambil setiap keputusan maka kita akan terjerumus kedalam tindakan yang salah pula. Tidak lupa juga untuk meningkatkan kreatifitas dan inovatif sebab dalam dunia kerja sikap ini akan memiliki nilai positif dalam menghadapi persaingan yang begitu ketat. Kemudian bijak yang dimaksud adalah dengan adanya ilmu pengetahuan yang sudah diperoleh dan juga teknologi canggih yang sudah tersedia saat ini, setiap manusia diharuskan menyaring atau memilah mana yang baik dan mana yang buruk. Misal ketika kita melihat ada uang yang dibawa oleh seorang ibu-ibu terjatuh, maka kita harus memungutnya lalu mengembalikan uang tersebut pada pemiliknya. Bukan lantas ibu tersebut tidak tahu dan langsung di masukkan ke celana kita. Sikap seperti itu harus tertanam dalam diri.

Berbuat baik harus menjadi prioritas yang utama agar kita dapat berjalan menuju kebaikan pula. Namun terlepas dari hal tersebut, sekarang ini banyak kasus yang sempat terjadi dan kebanyakan adalah tindakan yang melanggar hukum. Salah satunya adalah tindakan percabulan. Banyak sekali kasus yang terjadi dan menimpa khususnya pada kaum wanita. Kejahatan ini tidak hanya menyasar wanita yang sudah berumur dewasa atau usia 17 tahun keatas saja, namun banyak pula anak dibawah umur yang dijadikan sasaran oleh para pelaku. Tindakan percabulan sendiri merupakan perilaku menyimpang dan hasrat berlebihan yang menggebu gebu yang dimiliki oleh seseorang dan secara sadar maupun tidak sadar melecehkan orang lain dalam hal seksualitas.

Perilaku menyimpang ini umumnya biasa terjadi pada perempuan yang notabenya adalah lebih lemah dari pada laki-laki. Karenanya banyak laki-laki 
yang dengan semena mena ketika hawa nafsunya memuncak dan tidak terkendali melampiaskannya melalui tindakan cabul tersebut. Sekarang ini banyak berita yang menayangkan tindakan tersebut dan sesuai dengan undang undang yang berlaku di Indonesia, pelaku dihukum dengan pasal dan denda yang cukup besar. Meski dengan berbagai hukuman yang ada, angka kriminalitas dari tindakan percabulan tetap saja tidak mengalami penurunan. Malah justru dari tahun ke tahun terus mengalami peningkatan, dan tak kalah mengkhawatirkannya kasus percabulan sekarang ini dialami oleh anak dibawah umur.

Pada dasarnya anak dibawah umur mudah sekali terpengaruh dengan bujukan atau tawaran dari orang lain, apalagi dirayu dengan hal-hal yang disukai atau diminati oleh anak tersebut. Dengan tindakan yang terencana ini, pelaku dengan leluasa melakukan aksi bejatnya ketika tidak ada orang yang mengawasi. Tindakan percabulan seperti menjadi sebuah kasus yang mudah sekali terjadi, baik itu di keramaian apalagi ditempat yang sepi. Ada pula di suatu kasus bahwa beberapa waria yang mencabuli seorang anak berumur dibawah tahun. Terlihat bahwa waria pun yang menurut kebanyakan orang mereka itu laki-laki yang menyerupai dan bertingkah laku seperti perempuan yang menyukai sesama jenis pun melakukan tindakan menyimpang. Seakan tindakan ini tidak mengenal jenis kelamin, tempat, dan kondisi si pelaku. Perilaku yang menyimpang sebagai waria, ditambah dengan perilaku menyimpang lain yaitu mencabuli seorang bocah menambah "kegilaan" yang terjadi pada pelaku.

Kodratnya sebagai lelaki dan orang dewasa yang harus melindungi anakanak seakan dibantah oleh pola pikirnya. Tindakan ini bagaikan binatang yang melakukan sebuah tindakan tanpa melalui pikiran dan hanya menggunakan instingnya saja. Binatang beraktivitas tanpa memikirkan apa yang mereka inginkan, namun mengikuti insting alami. Ketika merasa haus mereka mencari sumber mata air, ketika lapar mereka mencari mangsa, ketika kawin pun mereka kawin namun ditempat yang bebas dan tidak tertutup.

Kembali lagi bahwa setiap mendengar tindakan kejahatan percabulan apalagi dialami oleh anak-anak dibawah umur. Pasti orang yang mendengar hal ini merasa geram dan ingin sekali melakukan tindakan anarkis untuk si pelaku. 
Namun juga hal ini tidak dibenarkan juga secara hukum karena akan menyakiti orang tersebut. Tindakan cabul selain melanggar hukum juga melanggar dalam sisi keagamaan. Setiap agama di dunia pasti mengharamkan tindakan perzinahan tersebut karena tindakan cabul merampas kebebasan orang lain. Kebebasan disini maksudnya adalah merampas hak orang lain untuk tidak disentuh kesuciannya baik itu bagian luar maupun dalam. Selain itu tindakan cabul juga menambah dosa bagi orang yang melakukannya. Persoalan ini membuat orang tua harus lebih waspada lagi dalam menjaga anaknya terutama putrinya agar tidak menjadi korban. Pengawasan yang ketat mungkin perlu dilakukan seperti mengetahui kemana anak anak pergi bermain dan aktivitas lain diluar rumah. Hal ini untuk mencegah hal-hal yang tidak diinginkan.

Apalagi zaman sekarang perkembangan teknologi yang canggih semakin menambah akses pelaku kejahatan seksual ini untuk beraksi. Seperti penggunaan media sosial facebook, instagram, dll. Diikuti dengan anak muda bahkan anakanak pun sudah memiliki telepon genggam yang bisa dengan mudah untuk mengakses internet semakin mempermudah pelaku untuk memperdaya korbannya dengan tawaran yang bermacam-macam. Penyalahgunaan semacam ini lah bukti nyata bahwa manusia semakin berilmu justru semakin bisa berbuat semaunya tanpa berpikir panjang dan mempertimbangkan masalah apa yang akan terjadi nantinya. Ketika berilmu manusia harus mengimbanginya dengan sikap bijaksana dalam beretika dan berpikir.

Artinya bahwa ilmu pengetahuan itu bisa membuat kebaikan bagi sesama namun juga keburukan bagi orang lain. Ilmu yang tinggi dalam menggunakannya perlu diterapkan sesuai dengan kebutuhan dan menuju pada kebaikan sesama manusia. Misalnya ketika terdapat suatu berita penting di internet atau media sosial apapun itu, tidak boleh menyebarkannya keorang lain dengan mengubah isinya dengan hal yang tidak baik apalagi menyebar berita palsu (hoax). Bagikan berita tersebut apa adanya atau bahkan memberikan saran agar berita ini tidak menimbulkan kekacauan jika isinya adalah kabar buruk.

Kembali lagi ke permasalahan bahwa perilaku menyimpang mungkin bisa terjadi dimana saja dan kapan saja, namun terlepas dari itu semua manusia harus 
belajar untuk menahan dirinya sendiri. Belajar mengontrol hasrat dalam diri dengan mengalihkannya dengan kegiatan lain atau dengan kesibukan lain. Sebagai mahluk yang diberkati dengan akal budi seharusnya pelaku merasa malu dengan tindakan cabul yang dilakukannya tersebut. Apakah pelaku ingin disamakan dengan binatang?. Hal ini lah yang patut di pahami oleh manusia agar tindakan menyimpang bisa di tekan bahkan dihilangkan dalam benak sesorang.

Sebagai manusia yang telah diciptakan Tuhan dengan berbagai macam kesempurnaan fisik, berpikir, bertindak, dan sebagainya harus memahami apa itu hakikat dari permasalahan intelek yaitu mengerti dan kehendak yaitu soal kemauan. Intelek disini memiliki makna untuk memilah apa yang baik dan apa yang buruk. Kehendak mengapresiasi ketika sudah melakukan suatu tindakan lalu dinilai meskipun itu baik maupun buruk. Kedua hal ini berjalan seiringan dan membentuk satu sama dengan yang lainnya. Dari sini juga terbentuk aspek rohani dan jasmani, dimana ketika jiwa ingin melakukan sesuatu yang terkait perbuatan itu baik atau buruk secara sadar maupun tidak raga akan merespon dan melakukan apa yang jiwa kehendaki.

Setelah itu dilakukan evaluasi secara intelektual menggunakan akal budi yang akan membentuk manusia menjadi manusiawi yang rasional. Manusia memiliki kebebasan, tetapi dilain pihak juga tergantung. Aliran Determinisme mengatakan bahwa manusia itu tidak bebas dan ditentukan oleh unsur-unsur lain (Hegel: Dialektika Roh, Spinoza: substansi mutlak penentu segala sesuatu, Carl Gustav Jung: manusia bergantung pada hukum yang ada) , sedangkan aliran indeterminisme mengatakan bahwa manusia itu bebas mutlak (Fichte: manusia menentukan dirinya sendiri, Atomistis: ssemua adalah peristiwa atom yang terjadi secara kebetulan. Dari berbagai pernyataan aliran dan para filsuf diatas terdapat pemahaman kebebasan yang berbeda beda. Semuanya belum tentu benar dan belum tentu salah. Dari diri sendiri harus dapat menarik kesimpulan mengenai makna kebebasan yang baik dengan cara intelektual dan rasional dengan tujuan untuk kebaikan bersama.

Untuk itu kehendak yang dimiliki oleh tiap manusia digunakan secara bebas karena tidak terikat oleh suatu hal, meski begitu dalam mengambil setiap 
keputusan harus dengan tetap bertujuan untuk kebaikan dan bukan ditujukan untuk keburukan apalagi untuk kehidupan orang banyak. Manusia memiliki apa itu yang namanya pendirian, dimana membuat manusia dapat bertindak dengan cara yang intelek dan dapat mempengaruhi orang lain.

Manusia ketika mendapatkan masalah kerja misalnya, saat dipecat atau dikeluarkan dari pekerjaannya karena alasan yang tidak dapat diterima, maka dengan pendiriannya ia akan merasa tidak rela dan menuntut kompensasi atau bahkan menghasut rekan kerjanya untuk demo terhadap perusahaan tersebut. Berbeda dengan hewan yang tidak punya pendirian sama sekali. Meski beberapa hal hewan memiliki kebebasan untuk beraktivitas, baik itu mencari makan dan minum sendiri, berpindah tempat tinggal atau hibernasi tanpa terikat oleh apapun.

Namun terlepas dari itu semua ia tidak memiliki kemampuan untuk mengatakan hal buruk pada hewan dan manusia bahkan menghasut sesama binatang untuk berperang terhadap manusia karena sudah merusak lingkungan dan ekosistem alam. Inilah yang menjadi pembeda antara manusia yang memiliki intelek secara bebas dengan hewan yang hanya menggunakan instingnya saja untuk melakukan suatu tindakan tertentu. Tindakan manusia terbagi menjadi dua yaitu actus hominis dan actus humanus.

Pengertian actus hominis sendiri merupakan suatu tindakan dasar sebagai manusia dan mahluk hidup berupa dapat bergerak, memiliki tingkah laku, insting, tidur, makan, minum dan ada didunia. Lalu untuk actus humanus lebih menekankan pada tindakan yang manusiawi yaitu memperhatikan tindakan yang baik dan memiliki etika yang baik pula. Tindakan ini memiliki nilai yang penting karena menyangkut rasio manusia dalam melakukan berbagai macam pengambilan keputusan yang bisa berdampak pada kebaikan maupun keburukan. Hal ini juga membuat manusia menjadi lebih paham mengenai alasannya untuk hidup sebagai manusia yang berguna bagi orang lain dan sesama yang sedang membutuhkan.

Pada tindakan percabulan ini yang ditinjau dari aspek intelek dan kehendak manusia merupakan hal yang perlu dipahami lebih mendalam lagi. Mengapa? Karena perbuatan tersebut menyangkut juga dengan kebebasan sebagai manusia 
itu sendiri. Manusia memang terlahir bebas dalam berpikir dan bertindak. Berpikir dengan menggunakan kapasitasnya sebagai manusia yang memanusiakan manusia. Tindakan seperti melecehkan manusia lain secara fisik sama saja merampas haknya sebagai manusia yang bebas dari ancaman manapun. Sebelum melakukan tindakan percabulan pada manusia lain pasti akan ada hal yang dipikirkan oleh si pelaku dan melakukan upaya bagaimana caranya agar ia dapat memuaskan hasrat duniawinya tersebut. Pola berpikir yang salah ini haruslah diubah dan sebisa mungkin dihilangkan.

Manusia memiliki akal budi yang sempurna dan sebagai rasio yang telah dimiliki, pastinya akan berbeda dengan hewan yang meskipun memiliki otak namun hewan tidak mengandalkan rasionya karena tidak memiliki akal budi. Tindakan hewan memanglah bebas namun mereka bergerak berdasarkan insting hewani mereka. Hewan tidak berpikir bahwa ketika melihat betina lain, ia akan terangsang dan ingin melakukan tindakan percabulan. Hewan hanya bertindak seperti itu ketika hormonnya sedang naik dan pada saat itu sedang musim kawin pula. Pada musim tertentu saja hewan saling melakukan hubungan tubuh. Apakah manusia yang dikatakan sempurna dapat disamakan dengan hewan yang hanya bertindak berdasarkan insting? Jawabannya terdapat pada diri manusia itu sendiri. Bertindak manusiawi berarti ia dapat mengontrol apa yang sedang dikehendaki dan diperbuat.

Manusia dikatakan sempurna jika ia secara tau, mau, dan bebas dapat berpikir sekaligus bertindak yang menuju pada kebaikan. Manusia tau dan sadar dengan apa yang sedang dikerjakan, manusia mau melakukan suatu tindakan tanpa paksaan dari manusia lain, manusia bebas apakah ingin melakukan tindakan tersebut ataupun tidak. Tindakan percabulan membuat manusia dapat dikatakan sama dengan hewan karena manusia membuang kebebasannya dalam berbuat kebaikan dan hanya mengikuti naluri birahinya saja serta ingin memuaskan kehendaknya secara sepihak. Hal semacam ini yang membuat manusia menjadi tidak sempurna lagi sebagai manusia. Rasio yang dimiliki sebagai manusia yang sempurna tidak digunakan untuk kebaikan membuatnya tidak ada bedanya dengan hewan. Intelek terganti dengan insting tanpa mengevaluasi dampak apa saja yang 
terjadi jika melakukan tindakan yang menuju pada keburukan. Kesadaran manusia haruslah digunakan sesuai dengan nilai manusiawi. Manusia tercipta berdasarkan actus hominis yaitu mahluk hidup yang dapat bergerak, makan, minum, memiliki insting, naluri dan ada didunia. Dalam hal ini, perbuatan yang dilakukan manusia hanya berjalan sebagaimana mestinya saja tanpa melakukan aspek rasionya yaitu berpikir.

Maka dari itu tindakan tersebut harus diimbangi dengan actus humanus dimana dalam melakukan kebebasan bertindak ia menghendakinya dan paham dengan apa yang sedang dilakukannya. Terkait pula dengan etikanya sebagai manusia yang manusiawi haruslah menuju pada kebaikan. Menggunakan akal budi sebagai pondasi dalam mengambil suatu keputusan tertentu menjadikan manusia memiliki kesempurnaan karena dapat membuat ia memiliki tujuan yang merujuk pada tindakan kebaikan. Manusia harus memanusiakan manusia lain. Memaksimalkan rasio yang dimiliki yaitu akal budi membuat setiap insan secara tau, mau, dan bebas berpikir kemudian bertindak untuk kebaikan bagi sesamanya tanpa merampas kebebasan orang banyak. 


\section{Daftar Pustaka}

Dewantara, A. (2017). Filsafat Moral (Pergumulan Etis Keseharian Hidup Manusia).

Dewantara, A. (2019). Diktat Kuliah Filsafat Manusia. 